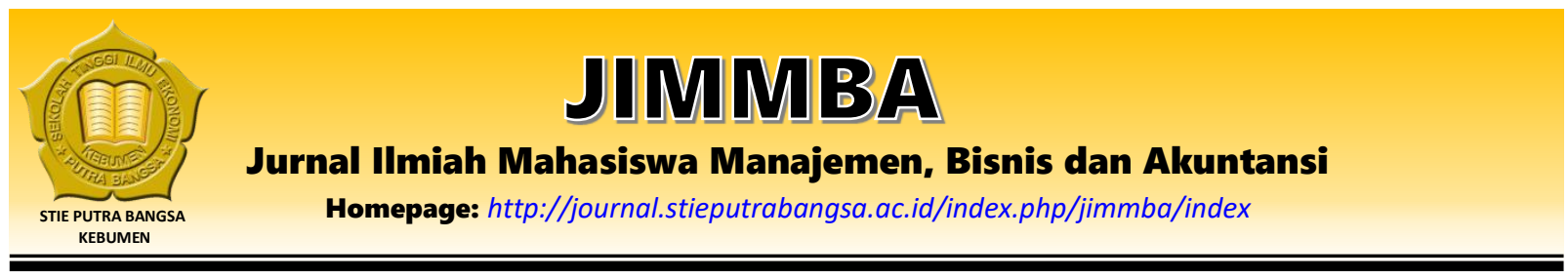

\title{
Sistem Informasi Akuntansi Atas Pengendalian Persediaan pada Rejeki 2 Swalayan di Omben Sampang
}

\author{
Ana Mafrudah', Halimatus Sa' diyah ${ }^{2}$ \\ 1,2 IAIN Madura \\ mafrudahana@yahoo.com ${ }^{1}$
}

\section{ARTICLE INFO}

Article History:

Received: August 29th 2021

Accepted: August 31 2021

Published: September $9^{\text {th }} 2021$

Keywords:

Accounting Information

System, Inventory Control

\begin{abstract}
This study aims to determine the accounting information system for inventory control at Rejeki 2 Swalayan in Omben Sampang. The type of research used is descriptive qualitative where the aim is to describe systematically the accounting information system for controlling merchandise inventory. Data were collected by means of observation, interview, documentation. The results showed that the accounting information system for inventory control owned by Rejeki 2 supermarkets in Omben Sampang was good. However, there are also weaknesses in the system, namely not using ledgers and auxiliary books. use ledgers and subsidiary books to facilitate transactions.
\end{abstract}

\section{Pendahuluan}

Berdirinya suatu usaha dagang akan memberikan berbagai manfaat terutama bagi pemilik usaha. Salah satu manfaat usaha yang bisa dirasakan secara langsung oleh pemilik usaha yaitu menambah penghasilan untuk memenuhi kebutuhan hidup. Menurut Achmad (2016), perusahaan dagang adalah perusahaan yang kegiatan utamanya membeli barang-barang dari pemasok (suplier) dan menjualnya kembali kepada konsumen tanpa mengubah baik wujud, fisik maupun sifatnya semula. Perusahaan dagang juga memiliki kegiatan untuk membeli dan kemudian menjual barang dagangan. Sehingga perusahaan harus selalu menyediakan stok barang untuk memperlancar jalannya suatu usaha dagang. Hal itu dikarenakan, persediaan barang merupakan hal yang sangat penting yang bisa mempengaruhi tingkat penjualan perusahaan.

Akan tetapi bila bahan baku yang dimiliki perusahaan melebihi kebutuhan yang direncanakan untuk keperluan proses produksi, maka perusahaan akan menanggung resiko biaya yang cukup besar, baik itu resiko akibat biaya penyimpanan maupun kerusakan bahan. Oleh karena itu para pengusaha atau pedagang tersebut harus dapat mengelola usahanya dengan baik. Hal ini yang paling penting adalah bagaimana cara perusahaan mengelola pengendalian persediaan barang dagangan dengan baik, sehingga dapat membantu masyarakat atau konsumen dalam memenuhi kebutuhannya. Kegiatan ini bukanlah hal yang mudah untuk dilakukan, karena dalam proses tersebut perusahaan tidak hanya harus menentukan jumlah yang tepat, agar barang dagangan yang akan dijual bisa 
sesuai dengan selera konsumen dan dapat disediakan dalam waktu yang tepat, tetapi diperlukan peranan pendukung lainnya yang dapat mempermudah suatu kegiatan yaitu sistem informasi akuntansi.

Sistem informasi akuntansi yang merupakan suatu alat yang dibuat secara ter struktur dan saling berhubungan untuk mencapai keefisienan dalam perhitungan keuangan dan keakuratan dalam pengambilan keputusan dalam perusahaan. Sistem informasi akuntansi dapat dikatakan sebagai prosedur pencatatan yang melaporkan berbagai informasi yang berkaitan dengan keuangan dalam suatu perusahaan. Pada jaman dahulu proses pencatatan dalam sistem informasi akuntansi masih dilakukan secara manual. Seiring perkembangan teknologi di era globalisasi ini, proses pencatatan secara manual tersebut perlahan-lahan telah beralih menjadi proses pencatatan yang terkomputerisasi. Peran sistem informasi akuntansi dalam proses bisnis sangat penting, karena informasi yang dihasilkan sangat diperlukan oleh pihak manajemen maupun para pengguna di luar manajemen perusahaan. Mayoritas berbagai bisnis perusahaan besar maupun kecil yang telah menggunakan pencatatan secara komputerisasi lebih mampu bersaing dengan para pesaingnya. Hal itu dikarenakan fasilitas CPU serta fasilitas pendukung lain seperti mesin kasir, barcode scanner, printer, dan sebagainya tersebut sangat membantu perusahaan dalam menjalankan aktivitas operasionalnya.

Peran sistem informasi akuntansi atas pengendalian persediaan bagi pihak perusahaan sangat penting karena sistem informasi akuntansi bersama-sama dengan sistem informasi lainnnya menyediakan informasi yang dibutuhkan manajemen sebagai dasar pengambilan keputusan. Peranan sistem informasi atas pengendalian persediaan, tidak terlepas dari fungsi yang dijalankannya. Bukan hanya sekedar pengolah atau pemproses data, tetapi sistem informasi akuntansi juga menjalankan mulai dari fungsi pengumpulan data, pemprosesan atau pengolahan data, manajemen data, pengendalian dan pengamanan data, serta tentunya fungsi penyedia informasi. Sistem informasi akuntansi merupakan struktur yang menjadi salah satu dalam kesatuan entitas yang menggunakan hardware untuk mengkonversikan data transaksi keuangan atau menjadi informasi akuntansi dengan tujuan memenuhi kebutuhan akan informasi bagi para penggunanya.

Sepertihalnya di Rejeki 2 Swalayan di Omben Sampang karena sistem infomasi akuntansi akan memudahkan bagi perusahaan dan pelanggan untuk melakukan proses pembelian dan pembayaran barang. Sehingga dapat meningkatkan minat seseorang untuk mendaftar menjadi seorang member yang nantinya akan membeli suatu barang yang dapat dilakukan dengan mudah dan memuaskan. Mengingat pentingnya sistem informasi akuntansi dan pengendalian persediaan sebagai sarana untuk menciptakan pengawasan dalam perusahaan, maka peneliti tertarik untuk meneliti tentang sistem informasi akuntansi atas pengendalian persediaan barang dagang yang ada di Rejeki 2 Swalayan Omben Sampang.

\section{Kajian Teori dan Telaah Literatur}

\section{Penelitian Terdahulu}

Penelitian terdahulu yang juga membahas tentang sitem informasi akuntansi, sebagai rujukan adalah sebagai berikut : Arifin dkk (2018) yang berjudul Analisis Sistem Informasi Akuntansi dalam Pengendalian Persediaan Barang Dagang pada PT. Kartini Teh Nasional 
Cabang Lumajang. Penelitian ini bertujuan untuk mengetahui efektivitas pengendalian persediaan barang dagang. Metode penelitian menggunakan kualitatif yang bersifat deskriptif, teknik wawancara dan dokumentasi tentang pengelolaan persediaan barang dagang. Dari hasil penelitian pengendalian yang dilakukan pada PT. Kartini Teh Nasional Cabang Lumajang masih memiliki beberapa kelemahan antara lain, terjadi penumpukan barang pada bagian gudang dan adanya ketidakcocokan jumlah persediaan yang ada di komputer dengan jumlah stok yang ada di gudang.

Penelitian terdahulu kedua dilakukan oleh Putra (2018) yang berjudulanalisis sistem informasi akuntansi dan pengendalian intern persediaan bahan baku kain(Studi Kasus Cv. Celine Productin). Penelitian ini bertujuan untuk mengatur atau mengumpulkan dan melakukan informasi mengenai semua transaksi perusahaan, di mana karyawan, kegiatan perusahaan, bahan dan mesin dapat diintegrasikan sedemikian rupa sehingga pengawasan dapat dilakukan. Sedangkan pengendalian internal adalah sistem yang digunakan untuk melindungi aset perusahaan, serta untuk menjalankan struktur organisasi dan menghasilkan informasi untuk mencapai tujuan. Hasilpenelitian tersebut Berdasarkan praktik yang terjadi di CV. Celine Production dengan melihat teori yang ada untuk sistem informasi akuntansi persediaan bahan baku pada fungsi yang terkait dan dokumen yang digunakan belum selesai dengan teori yang ada. Sedangkan sistem pengendalian intern persediaan bahan baku kain untuk struktur organisasi, praktik sehat yang dilakukannya, serta sumber daya manusia belum sesuai dengan teori yang ada. Dalam keadaannya memang belum sesuaidengan teori tetap perusahaan mampu menjalankan sistem informasi akuntansi dan system pengendalian internnya dengan baik.

Penelitian terdahulu ketiga dilakukan oleh Otinur dkk (2017) yang berjudul Analisis Sistem Informasi Akuntansi Dan Sistem Pengendalian Internal Persediaan Barang Pada Toko Campladean Manado, sistem informasi akuntansi dan sistem pengendalian internal adalah komponen yang mengumpulkan, mengklasifikasikan, memproses, menganalisis dan menggabungkan informasi keuangan yang relevan untuk pengambilan keputusan pihak luar (seperti pemerintah, masyarakat, investor, dan kreditor) pihak dalam (terutama manajemen). Penelitian ini bertujuan untuk menganalisis persediaan sistem informasi akuntansi dan diberlakukan di Campaldean Manado. Penelitian ini menggunakan metode penelitian deskriptif. Hasil penelitian menunjukkan sistem informasi akuntansi pada Campladean Manado masih menggunakan sistem manual dari sistem pengendalian internal tetapi sangat membantu dan mendukung sistem informasi akuntansi di Manado Campladean meminimalkan terjadinya kesalahan dalam sistem persediaan barang.

\section{Sistem Informasi Akuntansi}

Menurut Mulyadi (2016), Sistem informasi akuntansi adalah susunan beberapa dokumen, alat komunikasi, tenaga pelaksana, dan berbagai laporan komputer yang didesain untuk mentransformasikan data keuangan menjadi informasi bagi para pengguna.

Menurut Krismiaji (2002), sistem informasi akuntansi adalah sebuah sistem yang memproses data dan transaksi guna menghasilkan informasi yang bermanfaat untuk merencanakan, mengendalikan, dan mengoperasikan bisnis. Untuk dapat menghasilkan informasi yang diperlukan oleh para pembuat keputusan, sistem informasi akuntansi harus melaksanakan tugas-tugas sebagai berikut: a) Datatransaksi dan data lain Mengumpulkan danmemasukkannya kedalam sistem, b) Memproses data transaksi, c) Menyimpan data untuk keperluan dimasa mendatang, d) Menghasilkan informasi yang diperlukan dengan 
memproduksi laporan atau memungkinkan para pemakai untuk melihat sendiri data yang tersimpan di komputer, e) Mengendalikan seluruh proses sedemikian rupa sehingga informasi yang dihasilkan akurat dan dapat dipercaya.

Menurut Mulyadi (2016), unsur-unsur pokok sistem akuntansi adalah: a) Formulir merupakan dokumen yang digunakan untuk merekamterjadinya transaksi, b) buku besar terdiri dari rekening-rekening yang digunakan untuk meringkas data keuangan yang telah dicatat sebelumnya dalam jurnal, c) buku pembantu terdiri dari rekening-rekening pembantu yang merinci data keuangan yang tercantum dalam rekening tertentu dalam buku besar.

Tujuandari sistem informasi akuntansi adalah sebagai berikut: a) Untuk meningkatkan informasi, yaitu informasi yang tepat guna, tercepat, dan tepat waktu, b) Untuk meningkatkan sistem internal cek (pengendalian internal) yaitu pengendalian intern yang diperlukan agar dapat mengamankan aset perusahaan, c) harus dapat menekan biaya tata usaha, yaitu berarti biaya usaha untuk menyusun sistem akuntansi (biaya tata usaha berupa tenaga, alat tulis, dan kertas) harus seefisien mungkin.

\section{Sistem Akuntansi Persediaan}

Menurut Prasetyo dalam Tamodia (2013), persediaan adalah barang-barang yang akan digunakan untuk keperluan di masa yang akan datang. Persediaan yang meliputi barang dagang milik perusahaan yang dapat dijual kembali atau digunakan dalam proses produksi.

Ikatan Akuntan Indonesia (2015:14.2)persediaan meliputi barang yang dibeli dan dimiliki untuk dijual kembali.Seperti contoh, barang dagang yang dibeli oleh pengecer untuk dijual kembali, atau pengadaan tanah dan properti lainnya untuk dijual kembali. Persediaan juga mencakupi barang yang diproduksi, atau barang dalam penyelesaian yang sedang diproduksi oleh entitas serta termasuk bahan serta perlengkapan yang akan digunakan dalam proses produksi.

Menurut Laila (2018), Ada beberapa jenis persediaan, yaitu sebagai berikut : a) Persediaan bahan mentah, b) Persediaan komponen-komponen rakitan, c) Persediaan bahan pembantu atau persediaan bahan penolong, d) Persediaan dalam proses, dan e) persediaan barang jadi.

Menurut Tahlia (2018), Sistem pencatatan persediaan terbagi menjadi dua, yaitu: a) Sistem pencatatan periodik dilakukan dengan menghitung jumlah persediaan di akhir suatu periode untuk melakukan pembukuannya dan b) Sistem pencatatan perpetualmerupakan sistem pencatatan yang dicatat langsung saat transaksi tersebut berlangsung, semua akun langsung dapat diketahui pada saat transaksi berlangsung.

\section{Pengendalian Persediaan}

Menurut Assauri (2008), pada dasarnya pengendalian persediaan dimaksudkan untuk membantu kelancaran proses produksi, melayani kebutuhan perusahaan akan bahan-bahan atau barang jadi dari waktu ke waktu. Sedangkan tujuan dari pengendalian persediaan adalah sebagai berikut: a) Menjaga agar jangan sampai perusahaan kehabisan bahan- 
bahansehingga menyebabkan terhenti atau terganggunya proses produksi, b) Menjaga agar keadaan persediaan tidak terlalu besar atau berlebihan sehingga biaya-biaya yang timbul dari persediaan tidak besar pula, c) Selain untuk memenuhi permintaan pelanggan, persediaan juga diperlukan apabila biaya untuk mencari barang/bahan penggantian atau biaya kehabisan bahan atau barang (stock out) relatif besar.

Fungsi pengendalian persediaan menurut Siagian (2006)sebagai berikut : a) Apabila jangka waktu pengiriman bahan mentah relatif lama maka perusahaan perlu persediaan bahan mentah yang cukup untuk memenuh kebutuhan perusahaan selama jangka waktu pengiriman, b) Seringkali jumlah yang dibeli atau diproduksi lebih besar dari yang dibutuhkan, c) Apabila pemintaan barang hanya sifatnya musiman sedangkan tingkat produksi setiap saat adalah konstan maka perusahaan dapat melayani permintaan tersebut dengan membuat tingkat persediaannya berfluktuasi mengikuti fluktuasi permintaan, d) Selain untuk memenuhi permintaan langganan, persediaan juga diperlukan apabila biaya untuk mencari barang atau bahan pengganti atau biaya kehabisan barang atau bahan relatif besar.

Menurut Krismiaji (2010), di dalam sebuah sistem informasi akuntansi dibutuhkan flowchart, flowchart merupakan gambar atau bagan yang memperlihatkan urutan dan hubungan antar proses beserta instruksinya. Gambaran ini dinyatakan dengan simbol. Demikian setiap simbol menggambarkan proses tertentu. Sedangkan hubungan antar proses digambarkan dengan garis penghubung. Flowchart ini merupakan langkah awal pembuatan program. Dengan adanya flowchart urutan proses kegiatan menjadi lebih jelas. Jika ada penambahan proses maka lebih mudah dilakukan.

\section{Metode Penelitian}

Dalam penelitian ini metode yang digunakan adalah metode kualitatif. Menurut Sugiyono (2016), jenis penelitian yang digunakan adalah kualitatif, yaitu data yang berbentuk kata, kalimat dan gambar, yang berupa kumpulan data-data non angka yang bersifat deskriptif. Peneliti melakukan penelitian di Rejeki 2 Swalayan di Omben Sampang yang terletak di Jalan Raya Purlanjeng Omben Sampang.Peneliti melakukan penelitian dimulai dari bulan desember sampai selesai.

Teknik pengumpulan data yang digunakan dalam penelitian adalah sebagai berikut:

1. Wawancara (Interview)

Wawancara dilakukan guna mengetahui sistem informasi akuntansi atas pengendalian persediaan pada Rejeki2 Swalayan di Omben Sampang.Objekwawancara adalah: a) Pemilik usaha, b) admin, c) karyawan, dan d) Distributor

2. Observasi / pengamatan secara langsung.

Menurut Sugiyono ( 2016), observasi dilakukan untuk mendapatkan data primer dengan cara mengamati secara langsung praktek standar operasional prosedur (SOP). Pengamatan dilakukan tanpa harus terlibat dengan subyek penelitian, untuk menjaga obyektivitas.

3. Dokumentasi 
Teknik dokumentasi dilakukan untuk mendapatkan bukti-bukti penelitian yang dapat dipertanggung jawabkan. Selain itu merekam aktivitas di Rejeki 2 Swalayan di Omben Sampang. Media yang digunakan adalah foto.

Metode analisis data menggunakan teknik flowchart.

\section{Hasil dan Pembahasan}

\section{Sistem Informasi Akuntansi}

Sistem informasi akuntansi berdasarkan penelitian yang dilakukan di Rejeki 2 Swalayan Omben Sampang menggunakan aplikasi minimarket inventory system yaitu sebuah software atau perangkat lunak yang mengatur segala sistem penyimpanan barang. Termasuk dalam pengecekan dan penyediaan stok bahan baku atau barang jadi, untuk kelancaran proses produksi atau memenuhi permintaan pelanggan. Aplikasi tersebut memiliki beberapa manfaat seperti penyimpanan data, kontrol stok, meningkatkan efisiensi dan memberi kepuasan terhadap pelanggan.

Dari ulasan di atas dapat dipahami bahwa sistem yang digunakan di Rejeki 2 Swalayan Omben Sampang memiliki kesamaan dengan pendapat Krismiaji (2010). Rejeki 2 Swalayan Omben Sampang melakukan penginputan data barang pembelian yang sudah diperoleh dari hasil pembelian ke distributor atau suplier kemudianRejeki 2 SwalayanOmben Sampangmelakukan pemprosesan barang-barang tersebut untuk disimpan digudang dan akan dikeluarkan ketika Swalayan kehabisan stok persediaan olehpihak gudang untuk dijual kekonsumen.

Di dalam sebuah sistem informasi akuntansi dibutuhkan flowchart,flowchart merupakan gambar atau bagan yang memperlihatkan urutan dan hubungan antara proses beserta instruksinya. Gambaran ini dinyatakan dengan simbol dan setiap simbol menggambarkan proses tertentu. Sedangkan hubungan proses digambarkan dengan garis penghubung. Flowchart ini merupakan langkah awal pembuatan program. Dengan adanya flowchart urutan proses kegiatan menjadi lebih jelas, sedang Jika ada penambahan proses maka lebih mudah dilakukan. 
Adapun flowchart yang diterapkan oleh Rejeki 2 Swalayan di Omben Sampang adalah sebagai berikut:

Bagan 1. Bagian Alir Sistem Inforamsi Akuntansi Persediaan Barang

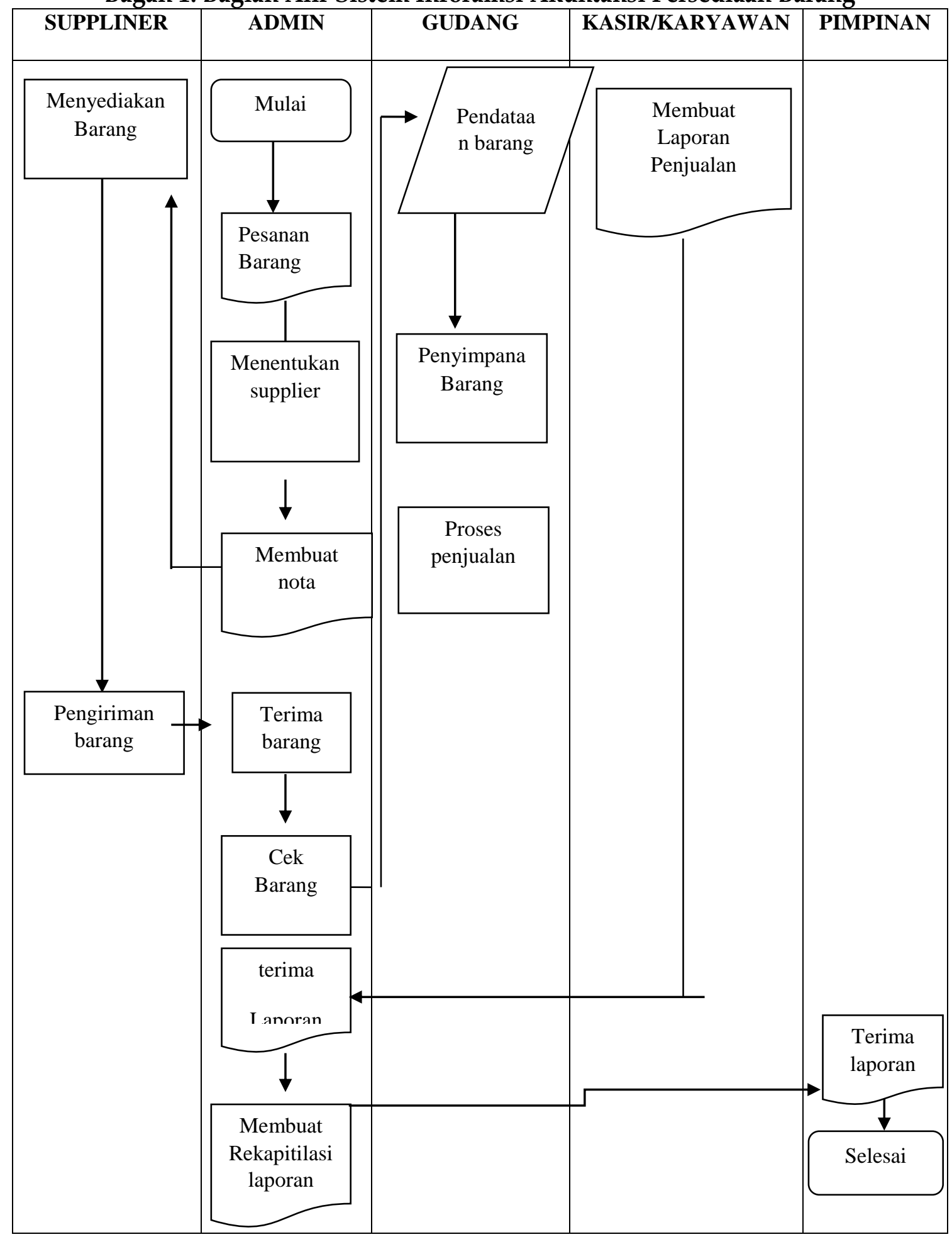


Dalam setiap kegiatan operasionalnya di Rejeki 2 Swalayan Omben Sampang mempunyai kegiatan masing-masing sesuai dengan bidang. Di mulai dari bagian admin yang melakukan pengecekan digudang dan mengontrol stok persediaan barang yang ada digudang serta mencatat barang yang sudah mulaihabis. Kemudian admin melakukan pesanan dan menentukan supplier untuk memesan barang. Sedangkan supplier menyediakan barang yang sudah dipesan oleh perusahaan dan mengirimnya. Setelah barang diterima oleh pihak perusahaan atau admin. Kemudian, admin melakukan pengecekan barang dan masukkan kedalam gudang.Sedangkan bagian gudang mendatanya dan menyimpannya. Proses penjualan berlangsung dan bagian kasir atau karyawan membuat laporan penjualan serta memberikan laporan tersebut kepada admin. Admin menerima dan merekapitulasi kemudian hasilnya diberikan kepada pemilik.

Sedangkan dalam setiap kegiatan operasionalnya PT. Kartini Teh Nasional Cabang Lumajang menerapkan beberapa kebijakan pengendalian untuk menjaga persediaanya, antara lain: pengawasan fisik, pengawasan akuntansi, pengawasan jumlah yang dibutuhkan.

Jadi, Sistem informasi akuntansi diRejeki 2 Swalayan Omben Sampang sudah menggunakan komputer untuk mengatur aktifitas di Rejeki 2 Swalayan Omben Sampang. Sistem informasi akuntansi sangatlah berguna dan mempermudah segala transaksi yang dilakukan oleh Rejeki 2 Swalayan Omben Sampang sudah memadai, meskipun kelemahanya tidak menggunakan buku besar dan buku pembantu padahal menurut Mulyadi (2016). Unsurunsur sistem informasi akuntansi diantaranya: formulir, jurnal, buku besar, buku pembantu, dan laporan hasil akhir.

Sistem yang digunakan Rejeki 2 Swalayan Omben Sampang menggunakan minimarket inventory systemyaitu, sistem inventory dimana, pengaturan persediaan dan berkaitan dengan aktivitas logistik sebuah perusahaan. Kegiatan dari sistem tersebut termasuk dalam pengecekan dan penyediaan stok bahan baku atau barang jadi, demi kelancaran proses produksi atau memenuhi permintaan pelanggan.Sistem pengolaan persediaan merupakan serangkaian kebijakan pengendaliaan untuk menentukan tingkat persediaan yang harus dijaga. Apabila jumlah persediaan terlalu besar (overstock) mengakibatkan timbulnya dana menganggur yang besar juga menimbulkan resiko kerusakan barang yang lebih besar dan biaya penyimpanan yang tinggi.

Namun jika pesediaan terlalu sedikit mengakibatkan resiko terjadinya kekurangan persediaan (stockout) karena seringkali barang tidak dapat didatangkan secara mendadak dan sebesar yang dibutuhkan, hal ini menyebabkan terhentinya proses produksi, tertunda penjualan bahkan hilangnya pelanggan. Jumlah stock barang di Rejeki 2 Swalayan sudah dilakukan pencatatan di komputer.

Untuk sistem informasi akuntansi pengendalian persediaan perusahaan PT. Kartini Teh Nasional Cabang Lumajang telah menggunakan formulir-formulir bukti transaksi, baik untuk pemesanan, pengorderan hingga nota pembayaran yang menunjang pemeriksaan data yang dilaukan oleh bagian akuntansi untuk menghitung jumlah pengeluaran yang dibutuhkan untuk menyelesaikan tipa order pemesanan barang pada perusahaan serta untuk penyusunan laporan keuangan seperti yang telah dilampirkan berupa laporan laba/rugi, dan neraca.melihat pada pembahasa tersebut dapat diketahui bahwa di perusahaan Teh tidak menggunakan sistem inventori. 
Persediaan mempunyai peran besar dalam rangka mempermudah atau memperlancar operasi perusahaan. Adapun tujuan pengelolaan persediaan adalah sebagai berikut:

1. Menghilangkan risiko keterlambatan barang tiba.

2. Untuk dapat memenuhi kebutuhan atau permintaan.

3. Menjaga keberlangsungan produksi atau menjaga agar perusahaan tidak mengalami kehabisan persediaan yang mengakibatkan terhentinya proses produksi.Memberikan pelayanan yang sebaik mungkin kepada konsumen dengan tersedianya barang yang diperlukan.

Berdasarkan hasil penelitian Arifin dkk (2018) yang berjudul analisis sistem informasi akuntansi dalam pengendalian persediaan barang dagang pada PT. Kartini Teh Nasional Cabang Lumajang yang didasarkan pada teori yang relevan terhadap masalah yang diteliti, penulis dapat mengambil kesimpulan sebagai berikut: Pencatatan yang tidak dilakukan secara rutin oleh pemilik toko ataupun bagian gudang, sehingga membuat pengendalian internal menjadi lemah. Adanya ketidakcocokan antara jumlah barang yang tercatat di komputer dengan jumlah stok yang ada pada gudang.

Dapat diketahui bahwa sistem informasi akuntansi yang ada di Rejeki 2 Swalayan lebih efektif dari pada sistem informasi akuntansi yang dikemukakan dalam penelitian Arifin, dkk (2018) pada PT. Kartini Teh Nasional Cabang Lumajang dikarenakan sistem informasi akuntansi di Rejeki 2 swalayan lebih rutin dikontrol oleh pemilik toko atau admin yang dilakukan 1 bulan atau triwulan. Sebaliknya, pencatatan yang kurang rutin dilakukan oleh pemilik toko atau bagian gudang di PT. Kartini Teh Nasional Cabang Lumajang sehinggamengakibatkan terjadinya kelemahan dipengendalian internal.

Pencatatan yang dilakukan oleh pihak Rejeki 2 SwalayanOmben Sampangyaitu secara manual dan menggunakan sistem yang ada di komputer (inventori). Segala yang berurusan dengan keuangan dicatat secara manual di buku khusus admin yang ada di Swalayan, dan semua hal yang berkaitan dengan transaksi, stok barang, laporan, pemesanan atau pembelian dan sebagaianya langsung terinput di komputer. Jika saja ada barang yang rusak baik dari distributor maupun retur dari pembeli maka yang dilakukan pihak swalayan yaitu menukar barang tersebut dengan barang baru tanpa mengurangi data barang yang telah terinput dalam komputer atau aplikasi inventori.

Langkah tersebut dilakukan agar pemesanan dalam pengendalian persediaan barang dagang tetap efektif serta tidak merancukan atau membuat pencatatan berubah-ubah sehingga laporan yang dihasilkan tetap valid. dari pernyataan tersebut membuktikan bahwa pencatatan yang baik sangatlah berpengaruh terhadap perkembangan dan kemajuan sebuah perusahaan. Sehingga untuk menilai seberapa baik operasional perusahaan selama periode tertentu dalam memenuhi pesanan yang ada di perusahaan. Bahkan jika dikaitkan dengan teori pengendalian persediaan yang menjelaskan bahwa pengendalian persediaan sebagai alat bantu utama dalam memecahkan masalah kuantitatif dalam sistem persediaan.

Melihat pada paparan di atas dapat dikaitkan dengan keadaan PT Kartini Teh Nasional cabang Lumajang yang kurang efektif dalam pengendalian persediaan barang dagang, dalam hal ini perusahaan melakukan pemesanan barang pada saat jumlah persediaan yang tersedia dalam gudang menipis, namun pada saat penerimaan barang tersebut hanya sebagian barang yang ada saat pemesanan dihitung sehingga terjadi penumpukan barang. 
Artinya pengendalian atas persediaan ini tidak dapat diperkirakan jumlah yang sebenarnya ada di gudang karena pencatatan yang dilakukan hanya pada saat barang yang dipesan tiba, namun jumlah barang yang tersisa tidak ikut serta dihitung dan tidak mampu mengetahui jumlah keseluruhan barang yang tersedia di gudang. Keadaan tersebut jelas berbeda dengan pencatatan yang diterapkan oleh Rejeki 2 Swalayan Omben.

\section{Sistem Pengendalian Persediaan}

Sistem pengendalian persediaan berdasarkan penelitian yang dilakukan di Rejeki 2 SwalayanOmben Sampangyaitu sistem inventory dalam makna pengaturan persediaan yang berkaitan dengan aktivitas logistik sebuah perusahaan. Di mana kegiatan dari sistem tersebut termasuk dalam pengecekan dan penyediaan stok bahan baku atau barang jadi,sistem pengelolaan persediaan merupakan serangka kebijakan pengendalian untuk menentukan tingkat persediaan yang harus dijaga. Apabila jumlah persediaan terlalu besar mengakibatkan timbulnya dana menganggur yang besar juga menimbulkanresiko kerusakan barang yang lebih besardan biaya penyimpanan yang tinggi.

Namun jika pesediaan teralu sedikit mengakibatkan resiko terjadinya kekurangan persediaan (stockout) karena seringkali barang tidak dapat didatangkan secara mendadak dan sesuai dengan yang dibutuhkan, sehingga menyebabkan terhentinya proses produksi, tertunda penjualan bahkan hilangnya pelanggan. Oleh karena itu untuk mencegah keterlambatan persediaan ketika mau mendekati hari Raya dimana distributor kebanyakan tutup ketika mendekati hari raya.

Maka solusi untuk mengatasi keterlambatan tersebut Rejeki 2 Swalayan membeli barang ke sales lain atau grosir untuk mengatasi persediaan yang kurang agar konsumen tetap terlayani untuk belanja di Rejeki 2 SwalayanOmben Sampang. Pengendalian persediaanminimarket inventory system paling dominan diterapkan di Rejeki 2 SwalayanOmben Sampang.Minimarket inventory system 'dapat mengatur persediaan dan berkaitan dengan aktifitas logistik disebuah swalayan,kegiatan sistem pengendalian tersebut dapat melakukan pengecekan barang, penyediaan stok barang demi kelancaran proses produksi dan bisa memenuhi permintaan pelanggan.

Dalam sistem pengendalian persediaan pada PT. Kartini Teh Nasional Cabang Lumajang telah menggunakan sistem manual dan terkomputerisasi serta lebih mengutamakan persediaan barang dagang yang dimiliki untuk memenuhi kebutuhan konsumen, namun masih adanya kekurangan yang terjadi karena jumlah stok barang yang tercatat dalam buku persediaan atau pencatatan di komputer tidak sama dengan jumlah stok barang yang ada di gudang.

\section{Penutup dan Saran}

\section{Simpulan}

Berdasarkan hasil analisis data dan pembahasan pada bab sebelumnya, maka dapat diambil kesimpulan sebagai berikut:

1. Sistem informasi akuntansi atas pengendalian persediaan pada Rejeki 2 Swalayan di Omben Sampang dapat dikatakan telah berjalan efektif, karena sudah sesuai dan memenuhi unsur-unsur pokok suatu sistem informasi akuntansi. 
2. Sistem pengendalian persediaan di Rejeki 2 SwalayanOmben Sampangsudah memenuhi kepuasan terhadap konsumen dengan menyediakan barang-barang yang menjadi kebutuhan konsumen, sehingga konsumen tidak merasakan kecewa ketika berkunjung untuk berbelanja. Selain itu Rejeki 2 SwalayanOmben Sampangdapat menjaga persediaan barang tidak terlalu berlebihan.

3. Pencatatan dalam sebuah perusahaan sangatlah penting bagi sistem informasi akuntasi dalam pengendalian persediaan. Seperti halnya pencatatan yang dilakukan oleh Rejeki 2 SwalayanOmben Sampangyaitu terdapat dua cara yang diterapkan yaitu segala yang berkaitan dengan keuangan maka pihak swalayan mencatatnya secara manual dalam sebuah buku khusus admin Swalayan. Sedangkan segala hal yang berkaitan dengan transaksi, persediaan barang, laporan, pembelian atau pembelian dan sebagainya langsung terinput di komputer.

\section{Referensi}

Abdillah, J. (2017). Perancangan Sistem Informasi Akuntansi Persediaan Bahan Baku Makanan Ternak pada Bagian Gudang di KSU Tandangsari Sumedang. Jurnal Riset Akuntansi dan Keuangan, 5(1), 1307-1324.

Arifin, M. Y., Indrianasari, N. T., \& Soemartono, S. (2018). Analisis Sistem Informasi Akuntansi dalam Pengendalian Persediaan Barang Dagang pada PT. Kartini Teh Nasional Cabang Lumajang. Counting: Journal of Accounting, 1(2), 162-170.

Gusdinar, I. R. (2016). Analisis Sistem Pengendalian Persediaan Barang Dagang pada PT. Adidaya Multi Niaga. Skripsi.Universitas Narotama Surabaya.

Indah, D. R., Purwasih, L., \& Maulida, Z. (2018). Pengendalian Persediaan Bahan Baku pada PT. Aceh Rubber Industries Kabupaten Aceh Tamiang. Jurnal Manajemen dan Keuangan, 7(2), 157-157.

Krismiaji. (2002). Sistem Informasi Akuntansi. Yogyakarta: Akademi Manajemen dan Perusahaan YKPN.

Mulyadi. (2016). Sistem Informasi Akuntansi. Jakarta: Salemba Empat.

Otinur, F., Pangemanan, S. S., \& Warongan, J. (2017). Analisis Sistem Informasi Akuntansi Dan Sistem Pengendalian Internal Persediaan Barang Pada Toko Campladean Manado. Going Concern: Jurnal Riset Akuntansi, 12(01).

Putra, R. E. (2018). Analisis Sistem Informasi Akuntansi dan Pengendalian Intern Persediaan Bahan Baku Kain (Studi Kasus CV. Celine Production). Jurnal Equilibria, 5(2).

Rahmadani, L. (2018). Penerapan Sistem Informasi Akuntansi pada Supermarket. Skripsi. Universitas Islam Negeri Sumatera Utara.

Romney, M. B., \& Steinbart, P. J. (2015). Sistem Informasi Akuntansi. Jakarta: Salemba Empat.

Sambara, T. A. (2018). Analisis Pengendalian Internal atas Persediaan Barang Dagang di PT. Xyz. Skripsi. Universitas Sanata Dharma.

Sugioyono. (2016). Metode Penelitian Kuantitatif, Kualitatif, dan RED. Bandung: Alfabeta. 